\author{
Agnieszka Tracz \\ Uniwersytet im. Adama Mickiewicza (Poznań, Polska)
}

\title{
Antroponimy w powieściach Ludmily Ulickiej (funkcje i cechy strukturalno-semantyczne)
}

Współczesna lingwistyka oscyluje wokół analizy treści wyrażeń językowych. XXI wiek wymusza zmiany we wszystkich sferach i aspektach życia człowieka. To właśnie te czynniki przyczyniły się do przemian w obszarze paradygmatu humanistycznego i do określenia jego bazowych funkcji, do których zaliczamy: kognitywizm, antropocentryzm, funkcjonalność. W związku z tym teoretyczno-metodologiczne podejście współczesnej lingwistyki poszerza swoje „terytorium”, mocno akcentuje obecność imion własnych i ich funkcjonowanie w tekście.

Językoznawstwo podkreśla ogromną rolę antropocentryzmu ze względu na związek człowieka jako językowego socjuma i indywiduum w lingwistycznych podsystemach. Uwadze filozofów nie umknęła kwestia językowego odzwierciedlenia świata poprzez stosowanie imion własnych. Takie zjawisko stało się niezwykle powszechne w badaniach nad językiem: «Онимия воспринимается как специфическая, автономная подсистема языка. Здесь иногда отражаются такие социальные, исторические, культурные факторы, которые не оставили следа в обычной лексике» (Юркенас 2004: 3).

Proza Ludmiły Ulickiej jest szczegółowo badana z punktu widzenia literaturoznawstwa. Już w latach dziewięćdziesiątych XX wieku krytycy literaccy zwrócili uwagę na charakterystyczny styl pisarki. O popularności jej powieści świadczą liczne thumaczenia książek na języki obce, ilość sprzedanych egzemplarzy czy mnogość prestiżowych nagród literackich: Медичи, Букер, Большая книга, Джузеппе Арцеби, Пенне etc. Nawet w obecnych czasach proza Ludmiły Ulickiej nie mieści się w kręgach zainteresowań lingwistów. Zatem aktualność naszego artykułu odnosi się do:

1. Istoty antropocentrycznego podejścia $\mathrm{w}$ badaniu określonego tekstu jako odzwierciedlenia świadomości i indywidualizmu pisarza;

2. Roli lingwistycznych i ekstra lingwistycznych cech antroponimów (Михайлов 2007:

W ludzkim świecie wszystko ma swoje oznaczenie, nazwę lub imię. Funkcjonuje szeroki wachlarz nazw, określeń, konkretnych imion lub niezwykle zło- 
żonych pojęć abstrakcyjnych. Według rosyjskiego filozofa A. Ф. Лосева wkład człowieka w rozwój onomastyki polega na nazywaniu konkretnych rzeczy, nadawaniu im imion, dzięki czemu świat staje się bardziej zrozumiały. Słowo, nazwa, imię stanowią swego rodzaju narzędzie pozwalające na codzienny kontakt z określonymi przedmiotami. Według Лосева «... в слове и, в особенности, в имени - всё наше культурное богатство, накопленное в течение веков» (Лосев 2000: 23). Badanie antroponimów w literaturze pięknej przyczyniło się do powstania oddzielnego kierunku. W związku z tym nazwami własnymi w obrębie onomastyki zajęli się językoznawcy, tacy jak: Л. П. Баганов, А. Л. Бем, И. Б. Воронова, Е. Б. Иванова, П. М. Бицилли, М. С. Альтман, В. И. Супрун, Ю. А. Карпенко, М. В. Горбаневский, Г. Ф. Ковалев і inni.

Forma antroponimiczna jest to określony porządek, który zmierza w kierunku różnych rodzajów antroponimów w procesie nazywania ludzi. «Русские антропонимы, образующие формулырусскогоречевогоэтикета, применяемые к друзьям, знакомым, родственникам в определённых ситуациях общения, во многом отличаются в этом качестве от собственных личных имён любого иностранного языка» (Листрова-Правда 1987: 4-12).

Motywy antroponimiczne związane są z cechami charakterystycznymi konkretnego języka i tradycjami nazywania ludzi. Mają one ścisły związek z historycznym i kulturowym rozwojem kraju, jednocześnie odzwierciedlają duchowy, wewnętrzny aspekt życia narodu. Proces rozwoju nazw to «непрерывный поиск наиболее удобной формы, в высокой степени отвечающей потребностям коллектива в чёткой идентификации личности, юридически закреплённой и соответствующей традициям, обычаям, своеобразной моде и, естественно, времени» (Королева 2000: 38).

Zbiór wszystkich antroponimicznych jednostek w powieściach Ludmiły Ulickiej tworzy swoisty system antroponimów, różniący się od parametrów innych znanych pisarzy.

W zależności od ilości struktur w antroponimicznej formie rozróżniamy modele jednosegmentowe, dwusegmentowe i trójsegmentowe. Szeregując je i wyodrębniając z powieści, takich jak: Даниэль Штайн, переводчик і Искренне Ваш Шурик można je podzielić na antroponimiczne formy uwzględniając tylko ilość komponentów. Dzięki temu Ulicka tworzy swoisty paradygmat nazw, które łączy ze sobą. Forma antroponimiczna nazw rosyjskiego człowieka to zbiór składający się z trzech komponentów. Stanowi to o jego identyfikacji, sytuacji, $\mathrm{w}$ jakiej znajduje się podmiot $\mathrm{z}$ uwzględnieniem okresu historycznego. Pisarka zastosowała następujące połączenie: nazwisko + imię + imię odojcowskie (dalej określane: $\Phi+И+\mathrm{O}$ ) w celu nadania cech indywidualnych podmiotowi: «В ходе оперативной проверки установлено, что Бенда Тереза Кшиштофовна, тайная монахиня, в 1975 году приняла постриг» (Улицкая 2006: 27). Model $\Phi+И+\mathrm{O}$ jest wykorzystywany w powieściach pisarzy, aby zapoznać czytelnika $\mathrm{z}$ bohaterem powieści oraz wyodrębnić i rozróżnić ich z grupy pozostałych posta- 
ci: «Третий адресат - Ионавичуте Анна Гедеминовна, заведующая отделом прозы литовского журнала Молодёжь Литвы В трудах Маймонида, известого в еврейских источниках как Моше Бен Маймон или Рамбам, иудейского учителя и комментатора XII века, встречаются острые выпады против христиан, столь же мало обоснованные, как и антиеврейские высказывания некоторых из отцов Церкви» (Улицкая 2006: 78). Ten trójsegmentowy model ma na celu przedstawienie ogólnego spisu ludzi. Taki zabieg pisarka zastosowała $\mathrm{w}$ dowolnym miejscu $\mathrm{w}$ powieści, co stanowi o jej przynależności gatunkowej do kroniki dokumentarnej: «В соответствии с договорённостью посылаю квартальный отчёт со списком граждан государства Израиль, принявших крещение за 1.01-25.03. 1985 года в храмах РПЦ.

1. Анищенко Пётр Акимович, г. р. 1930, Троицкое Подворье, Иерусалим.

2. Львовская Наталья Аароновна, г. р. 1949 - Эйн Карем, Горенский монастырь.

3. Рухадзе Георгий Ноевич, г. p. 1958 - Монастурь Св. Креста в Иерусалиме.

4. Рапопорт Раиса Семёновна, г. р. 1938 - церковь Св. Иоанна Воина, Беэр Шева» (Улицкая 2006: 92).

Model złożony z trzech komponentów $\Phi+И+\mathrm{O}$ jest charakterystyczny dla stylu formalnego: «Выявлен составитель заявления Брыкин Николай Васильевич, с которым была проведена соотв. работа» (Улицкая 2006: 134). W powyższych utworach model $\Phi+И+\mathrm{O}$ występuje w dziesięciu przypadkach: «Антищенко Петр Акимович, Брыкин Николай Васильевич, Ионавичуте Анна Гедеминовна, Кадомцева Ирина Алексеевна, Львовская Наталья Аароновна, Моше Бен Маймон, Рапопорт Раиса Семеновна, Рубин Андрей Иосифович, Рубина Елена Антоновна, Рухадзе Георгий Ноевич» (Улицкая 2006: 27). W ten sposób forma nazwisko + imię + imię odojcowskie w powieści Даниэль Штайн, переводчик sprzyja gatunkowym cechom utworu. Forma ta o charakterze mniej oficjalnym tworzy konotacje z uprzejmością, powagą, powściągliwością. Są one charakterystyczne dla stylu nieoficjalnego. W powieści pt. Искренне Ваш Шурик model И $+\Phi+\mathrm{O}$ został wykorzystany w dziewięciu przypadkach: «Александр Андреевич Корн, Елизавета Ивановна Корн, Александр Сигизмунтович Левандовский, Александр Николаевич Корн, Ирина Петровна Кругликова, Валерия Адамовна Конецкая, Галина Ивановна Лопатникова, Ирина Петровна Крутикова» (Улицкая 2008: 25). Celem takiego zabiegu jest odniesienie się do człowieka jako indywiduum. Ten proces jest widoczny w powieści Искренне Ваш Шурик w opisie rodziny głównego bohatera: «Отец ребенка, Александр Сигизмундович Левандовский, с демонической и несколько уцененной внешностью, с гнутым носом и крытыми кудрями, которые он, смирившись, после пятидесяти перестал красить, с раннего возраста обещал стать музыкальным гением; его дед, Александр Николаевич Корн, громоздкий, с большим твердым подбородком...» (Улицкая 2008: 58). 
We fragmencie powieści Искренне Ваш Шурик, kiedy główny bohater próbuje dostać się na jeden z wydziałów uniwersytetu, pewna kobieta zadaje mu następujące pytanie:

«- Кем вам приходится Елизавета Ивановна Корн?

- Бабушка. Она в прошлом году умерла. Шурик понятия не имел, что дама эта была той самой Ириной Петровной Кругликовой, которая лет десять домогалась профессорского места, занимаемого Елизаветой Ивановной» (Улицкая 2008: 141).

Powyższy przykład ukazuje antroponimiczny model dla nazw w 3 osobie i udowadnia, że każdy model posiada swoją specyfikę funkcjonowania, niepowtarzalność oraz odnosi się do stylu oficjalnego bądź nieoficjalnego. Analiza konotacji antroponimów składających się z trzech komponentów w powieściach Ulickiej nie ma aż tak szerokiego zastosowania. Spostrzeżenie to nasuwa wniosek, że dominuje dwukomponentalny model И $+\Phi$ i $\Phi+$ И. Przewaga dwusegmentowego modelu nad trójsegmentowym jest znacząca i wynosi 1:22.

Model składający się z dwóch elementów И $+\Phi$ przeważa nad modelem $\Phi+$ И: «Справа от Шурика сидел Вадим Полинковский, слева - Лиля Ласкин. Лучшим химиком в их подгруппе была Аля Тогусова, казашка на тонких недоразвитых ножках, сходившихся в единственной точке, в лодыжках» (Улицкая 2008: 168).

Nazwy własne dwusegmentowe w 3 osobie mogą występować również jako wyrazy przechodnie: «Вторая девица называлась Лена Стовба» (zamiast Елена); «Ну, а Наташа, Наташа Островская чем тебе не хороша?» Dominującymi dwusłownymi formami są konstrukcje typu: imię + imię odojcowskie (имя + отчество), na przykład: «Елизавета Ивановна, Матильда Павловна, Фаина Ивановна» (Улицкая 2008: 142).

Należy także przeanalizować funkcję отчеств w twórczości Ulickiej. Podstawowa rola, jaką spełnia imię odojcowskie, to forma wyrażania szacunku w stosunku do osoby, o której jest mowa: «Александр Николаевич, технический директор железнодорожного ведомства, человек европейского образования и безукоризненного воспитания, был начальником этого специального поезда». W gronie rodzinnym bohaterowie zwracają się do siebie, używając $И+\mathrm{O}$, aby podkreślić szacunek, jakim należy darzyć domownika: «C первого же дня обязанности поделили таким образом, что на долю Верочки приходилось кормление грудью, а все остальные взяла на себя Елизавета Ивановна» (Улицкая 2008: 76).

Imię własne $\mathrm{w}$ połączeniu $\mathrm{z}$ imieniem odojcowskim wskazuje na socjalny statut postaci, która zajmuje wysokie stanowisko: «Маму спрашивала еe начальница, Фаина Ивановна». Status materialny bohatera może mieć wpływ na И + O: «Геннадий Николаевич тоже три недели в том году отлежал у вас там, в Кремлевке... Геннадий Николаевич устроит - как членов семьи...» (Улицкая 2008: 94). 
Nieoficjalny styl męskich отчеств, w których sufiksy -ович, -евич przechodzą w sufiksy -ыч, -ич, wymusza fonetyczną kompresję: «Добро пожаловать, Сан Саныч - широко улыбнулся, сверкнув металлом» (Улицкая 2008: 65).

Należy podkreślić fakt, iż tradycje rosyjskiej literatury sięgają antroponimów, ściśle odnosząc się do struktury i modeli nazw. Nasze badania potwierdzają оріnię Ю. А. Карпенко: «писатель может видоизменять ономастические модели, по-своему интерпретировать ономастические нормы, но обычно он не нарушает принципа узнаваемости. Ведь имена персонажей и названия географических объектов в художественном произведении соотносят его действие с определенным местом (страной, языком), временем, социальной средой. И писатель по-этому не может не считаться с определенными ономастическими нормами» (Карпенко 1986: 34-40).

Istotną rolę w twórczości współczesnej pisarki odgrywa jednoczłonowy model nazw osób, który skrywa się pod postacią И + Ф. Można podzielić go na grupy:

1. Oficjalne formy nazw własnych to (Александр, Даниэль, Елизавета, Ефим, Мария itd.). Te antroponimy są nieprzechodnie i posiadają neutralny wydźwięk. W dużej mierze do grupy zaliczane są nazwy własne. W powieści Даниэль Штайн, переводчик pisarka użyła 1982 imion. Najbardziej powtarzane imiona: Даниэль (351 razy), Ефим (109 razy), Хильда (103 razy), Эва (71 razy), Эстер (63 razy), Михаил (34 razy). Większość imion jest żydowskiego, niemieckiego i polskiego pochodzenia, co jest ściśle związane z ideą, tematem powieści (polski Żyd zostaje tłumaczem z języka niemieckiego w gestapo). Antroponimy wyróżniają się ilością emocjonalno-stylistycznych wariantów, które wyrażają konotatywne znaczenia. Pełne nazwy imion posiadają charakter oficjalny, hipokratyczny czy ilościowy.

2. Jakościowe nazwy z subiektywnym wydźwiękiem to m.in. Шурик, Beрочка, Женька. Te imiona zaliczane są do grupy konotatywnej. W ten sposób antroponimy posiadające elementy zdrobnienia lub formę lekceważącą to Лилька, Алька, Ленка, Сонька, Катька, Туська itd. і z wykorzystaniem zdrobnienia: Аллочка, Лерочка, Катенька, Славочка itd.

Regularne użycie formantów o subiektywnym odcieniu ze zdrobnieniem: -к, -ик, -ечк, /-очк-, -еньк-/, -оньк itd. Do przykładów możemy zaliczyć: Лилька, Толик, Вадик, Жанночка, Веруся, Надюша, Филиппок.

W powieści Искренне Ваш Шурик najczęściej powtarzającymi się imionami były imiona jakościowe: Шурик (1266 razy), Лилька (81 razy), Верочка (38 razy), Аллочка (18 razy), Веруся (13 razy).

3. Imiona o wydźwięku neutralnym są przedstawione w formie skróconej: Соня (zamiast Софья), Катя (zamiast Екатерина), Женя (zamiast Евгений) itd. Do imion pospolitych zaliczamy: Мотя, Туся, Дуня, Тимоша, Матюша. Pisarka nie zapomina także o przestarzałych formach imion: Евдокия, Матрена, Поликарп, Тимофей. 
Ulicka korzysta również z zapożyczonych imion: Беата, Даниэль, Дитер, Жоэль, Матильда, Ганс, Энрике itd. Taki typ imion występuje w utworze Даниэль Штайн, переводчик, czyli w historycznej kronice.

Ważnym elementem pojawiającym się w prozie Ulickiej są jednosłowne antroponimy w postaci niezłożonych nazwisk. Przechodnią bazą nazwisk są rzeczowniki pospolite (Ведерникова, Лопатникова, Морозовы, Ласкина, Коробова, Столешников) i nazwy własne (Филипповы, Григорян). Natomiast nieprzechodnie nazwiska to nazwiska zapożyczone (Манн, Пелле, Шведт, Штамм) i historyczne antroponimy (Бах, Лермонтов, Мольер, Моцарт) (Формановская 2004: 71-77).

Antroponimy w powieściach Ulickiej w $49 \%$ są pochodzenia rosyjskiego, pozostałą część wyrazów stanowią zapożyczenia z następujących łaciny, języka tureckiego, niemieckiego, greckiego, grupy języków słowiańskich i skandynawskich.

Wykres 1. Etymologiczny zbiór antroponimów w powieściach Даниэль Штайн, переводик і Искренне ваи Шурик

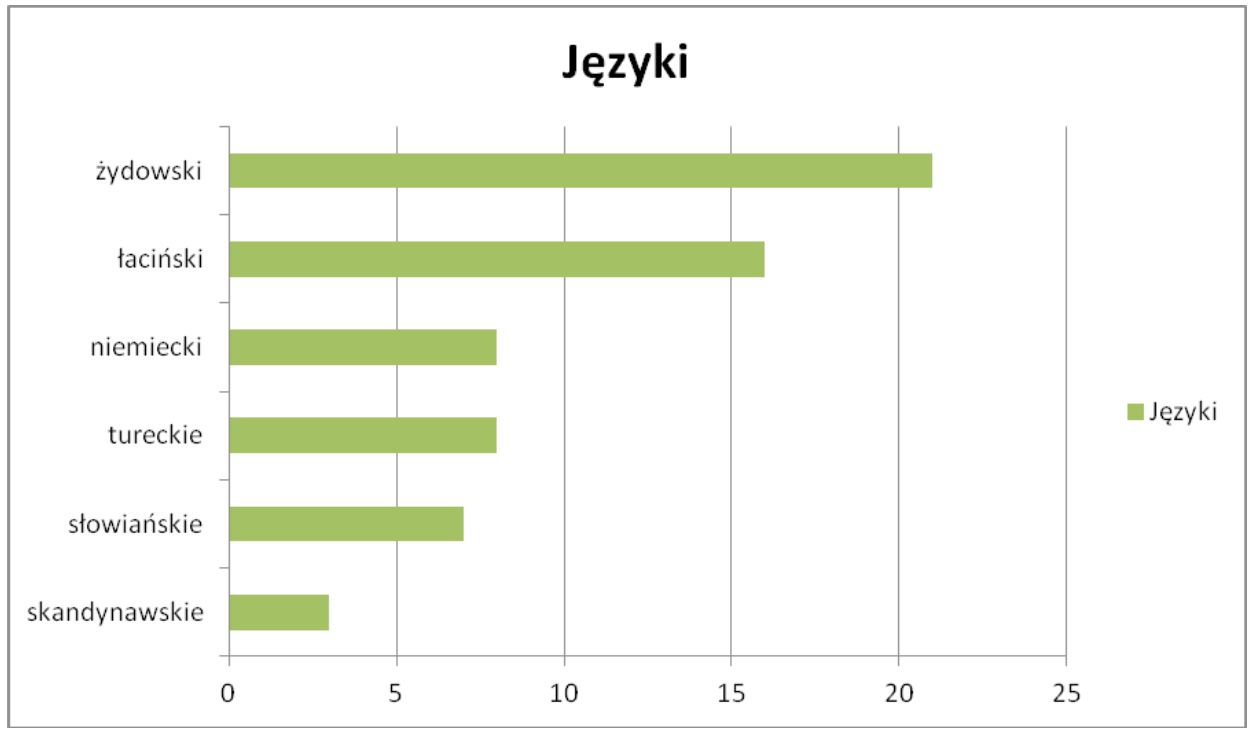

Języki: skandynawskie - 3\%; słowiańskie - 37\%; turecki - 8\%; niemiecki - 8\%; łaciński - 16\%; żydowski-21\%; grecki-37\%.

Imiona bohaterów występujących w prozie pisarki mają na celu podkreślenie problemów współczesnego świata m.in.: nacjonalizmu, stosunku do Żydów czy roli religii: «Он хорошо знает три - польский, немецкий и иврит. А другие, на которых он разговаривает, знает очень плохо. Но это не так: он водит группы на итальянском, испанском, греческом, французском, английском, румынском, говорил при мне с чехами, с болгарами и с арабами на их языке» 
(Улицкая 2006: 51). W powyższych powieściach pisarka użyła łącznie 244 nazwiska. Są one zamknięte w tzw. semantycznych grupach:

Nazwiska:

1) rosyjskie: Корнильев/Корнилов $<$ Корнилий Корний; Елисеев/Олисов/ Алисов $<$ Елисей/Олис/Алис (utworzone od nazwy zawodów);

2) białoruskie: Мочульский (utworzone od nazwy geograficznej);

3) ormiańskie: Григорян (utworzone od popularnego imienia nadawanego podczas chrztu);

4) europejskie: niemieckie: Мандельбаум<Mandelbaum, irańskie: Таиров arabskie: Tahir (czysty).

Taki etymologiczny system nazwisk podkreśla międzynarodowe więzi i wpływa na rozwój języka. Ma to ścisły związek z historią każdego narodu, jego tradycjami i kulturą.

W swoich powieściach pisarka wykorzystała więcej męskich imion. Proporcje zostały przedstawione na wykresie nr $\mathbf{2}$ :

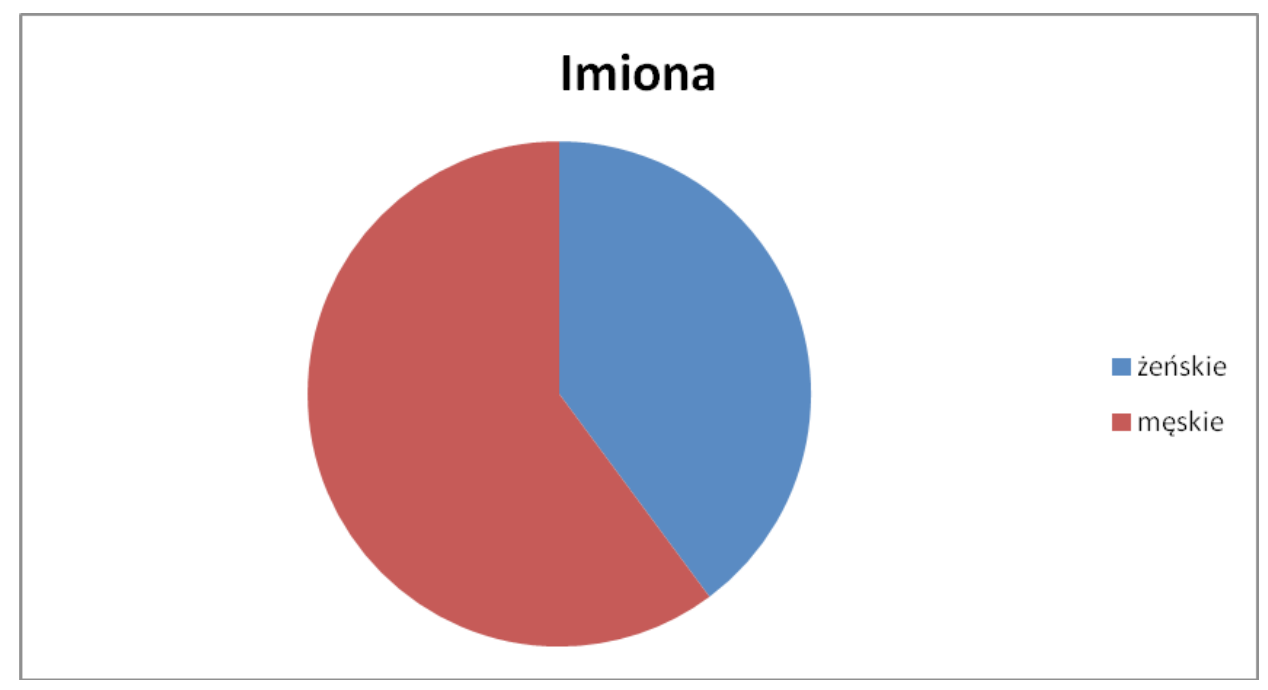

męskie - 157, żeńskie - 104

Imiona żeńskie odnoszą się do fabuły książki, natomiast męskie do trudnej sytuacji życiowej mężczyzn.

Krytycy często nazywają prozę pisarki proza niuansów, a większość tzw. paradoksalnych imion wynika $\mathrm{z}$ wewnętrznych pobudek pisarza-myśliciela, który chce wyjaśnić czytelnikom mechanizmy rządzące światem poprzez przeciwstawienie się okrutnej rzeczywistości. Lingwiści często wspominają paradoksy językowe, specjaliści w zakresie psychologii wspominają paradoks w stosunkach międzyludzkich, a Ulicka odnosi to do pragmatycznego podejścia, aby zakłócić proces komunikacji (Ковалев 2002: 75). 
Styl Ulickiej charakteryzuje się dbałością o szczegóły, która wpływa na fabułę tekstu, jego semantykę. Główny cel pisarki to zbliżenie się do danego narodu. Każde imię i nazwisko spełnia określoną funkcję i wpływa na kunszt literacki. Imiona mają związek z pojęciami kulturowymi. Wybór imion odnosi się do historii, kultury i mentalności narodu, do którego należy autor. Ulicka również podkreśla intertekstualny proces zachodzący między imionami oraz kształtuje światopogląd czytelnika w zakresie filozofii czy estetyki przy zastosowaniu odpowiednich antroponimów.

\section{Bibliografia}

Карпенко Ю. А. (1986), Имя собственное, «Литература» № 4, с. 34-40.

Королева И. А. (2000), Становление русской антропонимической системы, «СМИ» № 3, с. 38. Ковалев Г. Ф. (2002), Ономастические этюды, «Литературная Газета» № 5, с. 75.

Листрова-Правда Ю. Т. (1987), Выявление национально-культурной семантики номинативных языковых едении, «Русское слово» № 4, с. 4-12.

Лосев А. Ф. (2000), Онимия, «Современная литература» № 43, с. 23.

Михайлов М. (2007), Литературная традиция, «Современность» № 16, с. 5.

Улицкая Л. (2006), Даниэль Штайн, переводчик, Москва.

Улицкая Л. (2008), Искренне Ваш Шурик, Москва.

Формановская Н. И. (2004), Семантика, «Звезда» № 4, с. 71-77.

Юркенас Ю. К. (2004), Онимия, «Новый Мир» № 10, с. 3.

\section{Agnieszka Tracz}

\section{Examples of anthroponyms in the prose of Ludmila Ulitskaya. Their roles and structural semantic characteristics.}

\footnotetext{
Summary

In the prose of Ludmila Ulitskaya there is a wide range of anthroponyms which are connected with the personal names of human beings. The article analyzes their main roles in the text and wider cultural meanings.
} 